\title{
The Influence of Fault and Stress Contributed On Overpressure Mechanism For Neogen Formation (Mundu, Wonocolo, Ngrayong) East Java Basin, Indonesia
}

\author{
Fahrudin ${ }^{1, *}$, Hadi Nugroho ${ }^{1}$, Tri Winarno ${ }^{1}$, Zul Hayuddin ${ }^{1}$, Joko Suprayetno ${ }^{1}$, Rully \\ Firmansyah $^{2}$, Muhajir ${ }^{2}$, and Ade Kadarusman ${ }^{3}$ \\ ${ }^{1}$ University of Diponegoro, Semarang, Indonesia \\ ${ }^{2}$ Join Operating Body Pertamina PetroChina East Java (JOB-PPEJ), Indonesia \\ ${ }^{3}$ Independent Consultant, Indonesia
}

\begin{abstract}
Rembang Madura Kangean Sakala (RMKS) fault zone and W$\mathrm{E}$ structures of Kendeng Zone are the main structural elements in back arc basin, East Java, Indonesia. There are many perspectives about the overpressure zone at the basin. This research focus on the overpressure zone that related with formation and tectonic evolution. The study infer that high overpressure is explained by regional and local mechanisms. The results of analysis of log derived porosities at Karang Mudi-1 (KM-1) well indicate that high overpressure and overpressure was Neogen Formation (Mundu, Wonocolo, Ngrayong). Pore pressure prediction at KM-1 exerted Eaton's method. There are two overpressure zones at depth $2.680-4.900$ fTVD (B Zone) and $5.600-8.400$ fTVD (D Zone). High overpressure D Zone are regionally caused by flexural structure (anticline and fracture) from transpression setting (West - East RMKS). High overpressure in $\mathrm{KM}-1$ is transpression setting early which the overpressure follow the popup boundary. Area of high overpressure always related with fault thrust. Static mechanism is possible in the present day interplate stress field. Present the maximum horizontal stress was NEE - SWW. Local mechanisms occurs illitization at D zone from depth $6.800-8.400$ fTVD. $\mathrm{D}$ Zone is unloading mechanism (illitization and lateral transfer open fracture).
\end{abstract}

\section{Introduction}

Area of the active margin has specific tectonic and sediment characterization that generate a unique overpressure zone. This zone is also influenced by the history of tectonic evolution. The East Java Basin is an active sedimentary basin that has several high, normal, low overpressure zones [1]. The tectonic and active sedimentary related with overpressure. In case of the Watukosek fault [2] and the basement configuration appears to control the presence of overpressure [3]. Fault is driven by pressure and a source of fluid at structure

*Corresponding author: fahru_gabru@yahoo.com 
area on the compressonal tectonic belts, while initiated by fracture propagation [4]. The fractures or faults caused the lateral transfer of fluid (Yardly and Swarbick, 2000 in [5]). The Oligo-Miocene to Recent basin was filled with shallow marine deposits, some of which are known to be "overpressured" [6]. As a result of the compressional inversion, these strata are gently folded with normal and reverse faults cutting the inversion anticline crests [7]. Overpressured lower Miocene clays probably equivalent to the Tuban, Tawun and Kujung Formations [8]. Overpressure mechanisms include loading, unloading and tectonic control mechanisms.

Unloading refers to any process that tends to reduce the effective pressure. The process in unloading mechanism is the increase of fluid volume in the pore (fluid expansion) or by the loading transfer from the matrix to the fluid in the pores of clay mineral diagenesis such as smectite to illit or kaolin to illit and gas generation (oil cracking). Fluid transfer in the sandstone is also included in the process that can occur in the unloading mechanism, where the sandstone is isolated in the shale lithology unit. Overpressure zone is also associated with mud volcano. The shallow overpressured zone beneath the transition zone could partially reflect the presence of open fractures associated with a strike slip fault and relate with basal detachment fault [9].

This study conducted in order to better understand and other perspectives about the overpressure zone in East Java Basin associated with the formations and the tectonic evolution. Tectonic evolution at active margin and continental collision maybe give contributions this case. How influence fault and insitu stress controlled mechanism of overpressure.

\section{Methods}

This paper describes regional stress, regional geology, distribution of overpressure, and the seismic around KM-1 well. That seismics include inline 1500, cross-line 5686, and arbitrary line is presented the structure model around this well. Then, we interpret data of the logs, drilling problems, and leak of test (LOT). The logs data are gamma ray, density, sonic and resistivity logs. Log data is used to predict the value of sub-surface pressures with the help of Drillworks Predict software. These log data are also used to interpret composite lithology properties such as the interpretation of sediment compaction associated with Normal Compaction Trend (NCT) and sonic log trends. The lithology property is then associated with the pressure graph that is one of the ways in identifying overpressure characteristics. The pressure graph data has shown the existence of overpressure and normal pressure zone to depth. This research also supported by XRD, petrography, RO analysis and SEM-EDS data.

\section{Results}

The East Java Basin onshore is an extensional inversion basin with different basement characterizations. The basement was the result of collision from transition zone of Sundaland with Gondwana microcontinent on Late Creatceous. There are two characterizations of the basement structures, basement with NEE-SWW direction and E-W direction. It is reflected in the reverse fault of the subsurface (derived from seismic data) on the geological map (Fig. 1a). The western part of East Java Basin has a structure with NEESWW direction and the eastern part has an E-W structure. Geological cross sections show that the basement control causing the highland of Kendeng Zone and the lowland/highland of Rembang Zone (Fig. 1b). The higher part of Rembang Zone is the overpressure area and the lower one is at normal pressure. Subsidence/sagging and the early of tectonic 
compression is dominated by the deposition of shale (Fig. 1c). The pre-existing fault structure of fracture basement and rifting structure (normal fault) on the Plio-Pleistocene tectonic reactivated and uplifted.

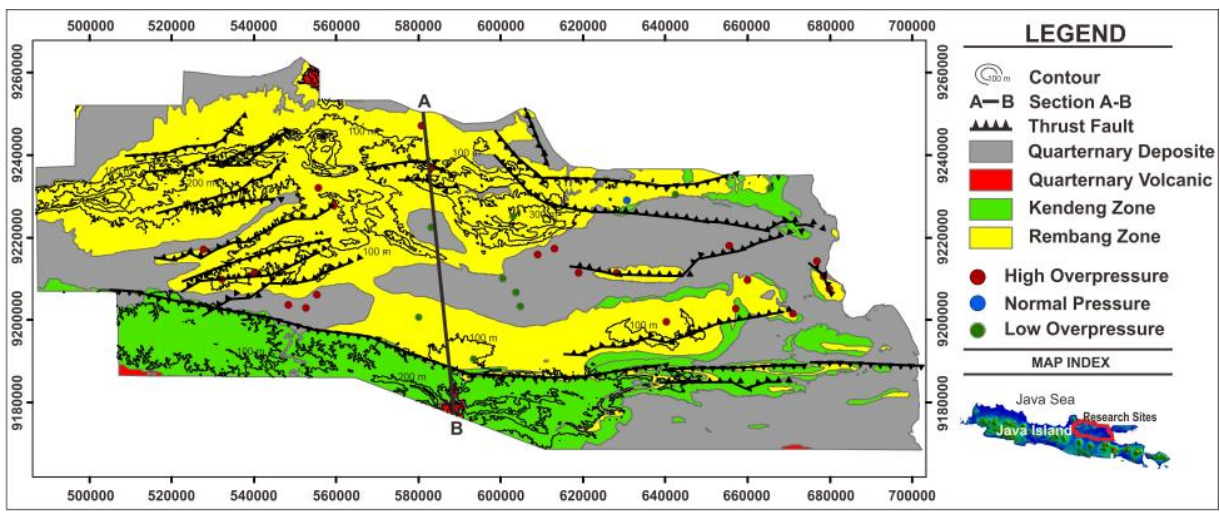

(a)

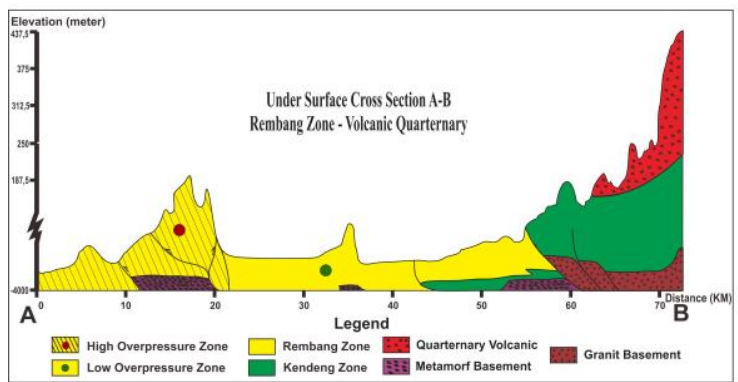

(b)

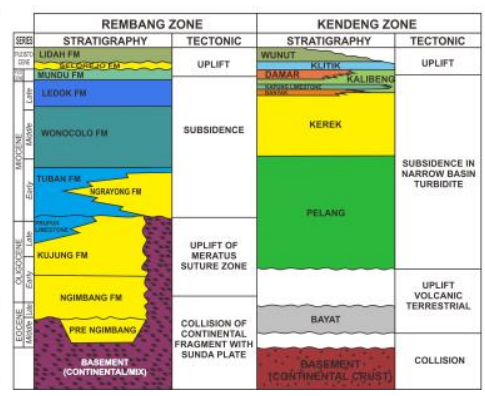

(c)

Fig. 1. (a). Regional Geology (b). Geological Cross Section (c). Stratigraphy of Rembang Zone.

Mechanisms for the high fluid overpressure are probably coused by basement control or structural patterns. There are two large structures found in the basin, the RMKS structure in the form of sinistral strike slip fault and Kendeng fault in the form of thrust fault. The overpressure zones are clustered into two zones, the western zone with the area of NW-SE direction and the eastern zone with the area of E-W direction. Both zones are truncated by RMKS fault. The current stress rating with a value of $8-7 \mathrm{~mm} /$ year was recorded in the Kendeng Zone, while in the Rembang Zone is about $<7 \mathrm{~mm} /$ year. The stress direction of the NE-SW is due to subduction in the southern of Java. The Kendeng fault is an active fault as well as the eastern RMKS part is also active. This stress contributes to lateral stress that can control the possibility of pressure in the eastern part of the basin (Fig. 2). In EF cross section shows the thickness of the Ngrayong Formation that is different, above the body of the limestone grows relatively thin when compared with the wings part of Tuban Formation (Fig. 3a). In line AB, showing the thickness of the Ngrayong Formation is different, indicating there is flexural due to fault, folding and subsidence. This indicates instability in the Ngrayong zone, this is correlated with pore pressure data and it is predicted that, this zone is a high overpressure area. The line seismic AB indicates there is compression to form a thrust fault and fold. The line seismic CD also indacates there is the beginning of transpressional compression fault. Around the faults in the $\mathrm{AB}$ seismic line there are X Well and KM-1 Well (Fig. 3a). 


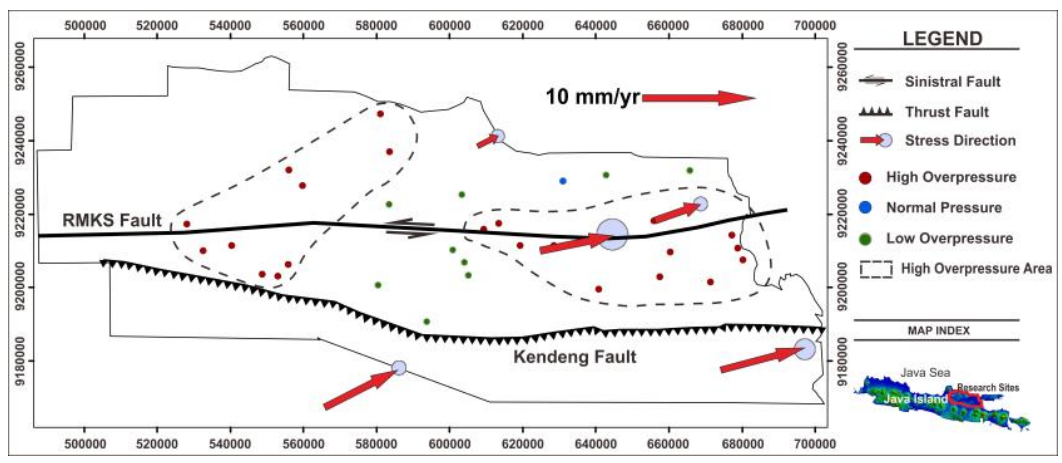

Fig. 2. Regional Stress and Major Structure.

Normal pore pressure analysis is performed on two logs i.e resistivity log and sonic log. In Eaton's method, the vertical effective stress, $\sigma_{v}^{\prime}$, is estimated from the measured sonic transit time, $\Delta \mathrm{t}$, using the equation:

$$
\sigma_{v}^{\prime} / \sigma_{n}^{\prime}=\left(\Delta \mathrm{t}_{\mathrm{n}} / \Delta \mathrm{t}\right)^{3}
$$

where $\sigma_{n}^{\prime}$ and $\Delta \mathrm{t}_{\mathrm{n}}$ are the vertical effective stress and sonic transit time on the normal compaction curve for hydrostatic pore pressure at the depth of measurement. There are two overpressure zones, (Figure 3b), as follows: B Zone, this zone is an overpressure found in the middle to the lower part of Mundu Formation (2,680 - 4,900 ftTVD). D Zone, this is an overpressure zone which form build up or called with high overpressure. This overpressure is found in the upper Wonocolo Formation to the lower Ngrayong Formation $(5,600-8,400$ ftTVD). Gamma-ray logs show the dominant lithology of claystone (shale), but at the depth of 5700 ftTVD, 7500-7800 ftTVD and 9200-9400 ftTVD show sandstone lithology. Effective pressure also shows varying trends in depth as it is controlled by intensive sedimentary compaction. Chemical compaction takes place predominantly in this zone due to rising temperatures. Authigenic mineral precipitation is quite abundant with distinctive characteristics. Based on XRD analysis, mineral composition on KM 1 Well are illite and smectite with the high percentage found on Wonocolo and Ngrayong Formation. This condition followed by the decreasing of the smectite. The petrographic thin sections show that the precentage of clay minerals are $>30 \%$ on Wonocolo and Ngrayong Formation. SEM analysis at $2280 \mathrm{ftTVD}$ with the composition of sheet structure of illite, and the illite at $6600 \mathrm{ftTVD}$ show the different structure, which more dense. The result of RO analysis is the early mature stage $(0.58 \%)$, where the organic matter has shown a change to the oil phase. This stage occurs in the lower Ngrayong Formation at about $9000 \mathrm{ftTVD}$ depth.

\section{Discussions and Conclusions}

The overpressure prediction analysis on the KM-1 Well indicates the presence of overpressure zones from sonic log trend analysis with the Normal Compaction Trend (NCT) which are B zone and D zone. The red circles represent overpressure zones in KM-1 Well, the green circles are the low overpressure zones, and the blue circles are the normal pressure zones (Fig. 1a). The area nearby RMKS fault has higher overpressure value than the further area (normal pressure and low overpressure zones). The location of KM-1 Well shown to explain that the area is surrounded by EW reverse fault. Regionally (Fig. 2), the eastern area tend to have overpressure zone and its spreading horizontally, while the 
overpressure zone in the western area tend to spread with NE - SW directions. The difference between these two overpressure zones are truncated by the major structures of RMKS fault.

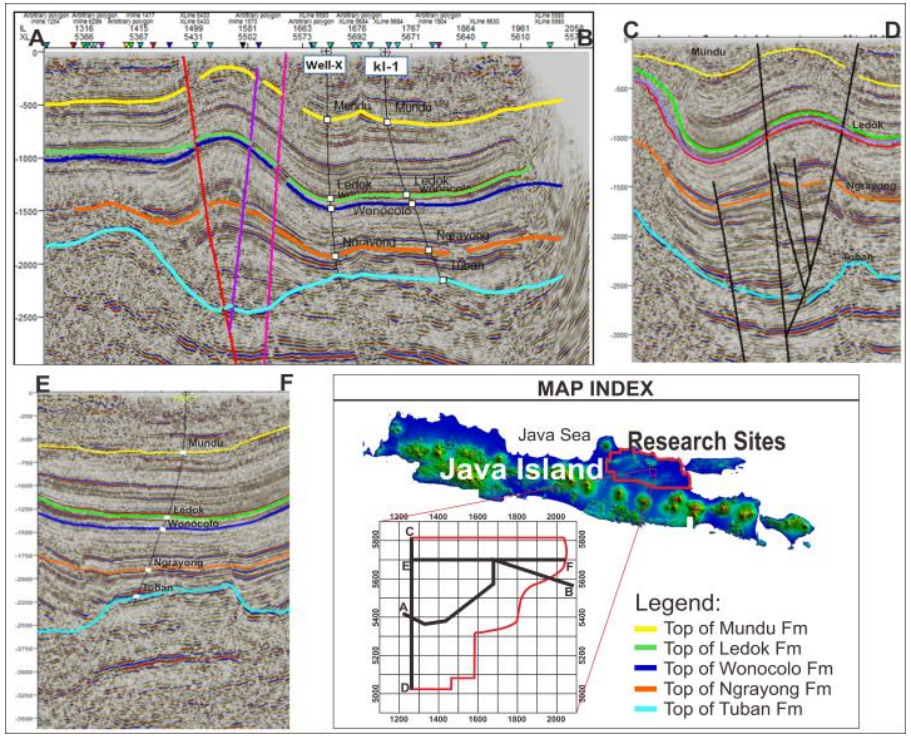

(a)

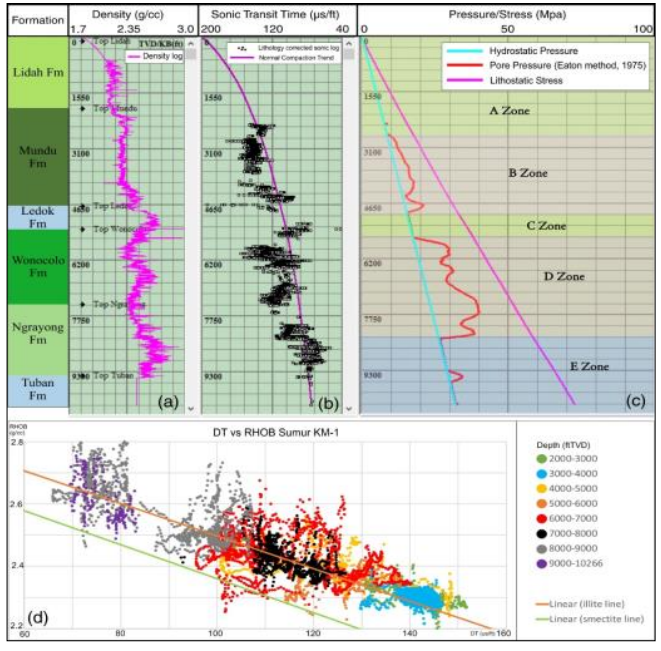

(b)

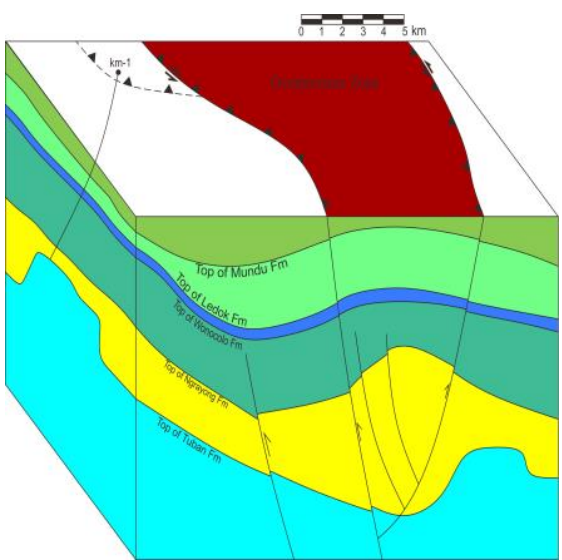

(c)

Fig. 3. (a). Picking Horizon Fault of Seismic Line $A B, C D$, and EF of the KM-1 Well (b). Overpressure zone contains B zone and D zone (c). 3D Modelling of Geological Structure and Overpressure Zone on the KM-1 Well.

The different overpressure direction is controlled by tectonic evolution of the North East Java Basin. The characteristics of geological structures of East Java Basin show the difference of two main patterns i.e E-W pattern on eastern part and NEE-SWW pattern in western part. So this shows the similarity between the spread of overpressure zone in the research area. In the western part it is a spreading zone that tends to have NEE-SWW 
directions that represent regional geological structure characteristics with a meratus pattern. The influence of geological structures in the form of faults have a very dominant contribution to the presence of ovepressure in this study area. The overpressure zone modeling which shows the vertical view of the sides and at the top 3 dimensions from the well of KM-1 (Fig. 3c). This is obtained from fault analysis by picking on seismic line AB, $\mathrm{CD}$ and EF. It can be seen that the zone around the KM-1 Well has an overpressure zone that is controlled by a reverse fault. The vertical presence of the geological structure shows the flower structure through the Tuban Formation - Wonocolo Formation. The three formations are controlled by a reverse fault that cause block one move up against to the other block and produce different thicknesses due to the influence of geological structures. This is of course correlated with the pore pressure prediction analysis found in zone B and zone D indicating the presence of ovepressures in Ngrayong and Wonocolo Formations. That fault is component of RMKS faults which have transpression setting that is still active now. The effect of the structure produces an unstable zone resulting in an overpressure zone at KM-1 well. The contribution of this faults to the mechanism of overpressure is interpreted that the RMKS faults are pathways which result in the existence of lateral fluid transfer between the rock layers at the KM-1 Well.

Based on the analysis, it can be concluded that overpressure zone in this area influenced by unloading mechanism which is controlled by transpression setting of RMKS fault and present stress at this fault. The presence of geological structures in the form of RMKS fault and Kendeng faults as a result of tectonic inversion occur in Early Miocene getting up until now reached $6-7 \mathrm{~cm} /$ year that produce an overpressure zone.

\section{References}

[1] A. Koulali, S. McClusky, S. Susilo, Y. Leonard, P. Cummints, P. Tregoning, I. Meilano, J. Efendi, A.B. Wijarnarto. The kinematics of crustal deformation in Java from GPS observations: Implications for fault slip partitioning. Earth and Planetary Science letters. 458, 72 (2017).

[2] A. Mazzini, A. Nermoen, M. Krotkiewski, Y. Podladchikov, S. Planke, H. Svensen. Strike slip faulting as a trigger mechanism for overpressure release through piercement structures. Implications for the Lusi mud volcano, Indonesia. Marine and Petroleum Geology J. 26, 1751 (2009).

[3] Agus M.R, Fahmi H, Lambok M.H, Neil R.G, Wuryadi S, Maikel A, Fatrial B, Kharisma E, Rully F, Risdi M.Z, Meyman Y.G, Sihman M, Purwo H.S, Agus H.P. Importance of understanding geology in overpressure prediction: The Example of The East Java Basin. Procc. IPA Thirty Seventh Annual Convection \& Exhibition. IPA13G-152 (2013).

[4] R.J. Davies. Birth of a mud volcano: East Java, 29 May 2006. Durham DH1 3LE. (2006).

[5] Bowers, G. L, Detecting Overpressure. Applied mechanics Technologies. Houston, Texas, U.S (2002).

[6] Osborne, M.J, and Swarbrick, R.E. Mechanisms for generating overpressure in sedimentary basins : A reevaluation. AAPG Bulletin, 81, 1023-1041 (1997).

[7] Mattews, S.J and Bransden P.J.E. Late Cretaceous and Cenozoic tectonostratigraphic development of the East Java Sea Basin, Indonesia. Marine and Petroleum Geology J, 12, 499-510 (1995).

[8] JOB-PPEJ and LPPM Undip, Final Report of Study Geomechanic, unpublished (2016)

[9] T. Tsuji, R. Kamei, R. Gerhard Pratt. Pore pressure distribution of a mega-splay fault system in the Nankai Trough subduction zone: Insight into up-dip extent of the seismogenic zone. Earth and Planetary Science letters. 396, 176 (2014). 